\title{
NEW TRAINING TECHNOLOGIES AND THEIR USE IN TRAINING AND DEVELOPMENT ACTIVITIES: SURVEY EVIDENCE FROM LITHUANIA
}

\author{
Vilmantė Kumpikaite்1, Ramunė Čiarniene் ${ }^{2}$ \\ Kaunas University of Technology, Lithuania \\ E-mail: ${ }^{1}$ vilmante.kumpikaite@ktu.lt; ${ }^{2}$ ramune.ciarniene@ktu.lt \\ Received 12 November 2007; accepted 25 February 2008
}

\begin{abstract}
There is emerging evidence that new technologies are related to improvements in productivity. Nevertheless, in considering the relationship between new technology and productivity, it is vital to consider human resource management and development issues due to their mediating effects on the relationship between new technology and productivity. This paper focuses on training technologies, especially e-learning. The increasing use of new technologies to deliver training and to store and communicate knowledge means that trainers must be technologically literate. That is, they must understand the strengths and weaknesses of new technologies and implementation issues such as overcoming users' resistance to change. The paper reports the findings of a study of 724 Lithuanian employees, which revealed relatively weak usage of new technologies and e-learning in human resource development processes.
\end{abstract}

Keywords: training technologies, e-learning, Lithuania.

\section{Introduction}

A key managerial task and expertise is to be able to operate effectively within the constraints of a changing environment. The changes that have impinged on society recently, have deeply affected the management of organizations. These changes may be summarised as: technological, social, economic, macro-political, ecopolitical and expectational. In this paper, the authors focus upon the training and development of employees using new learning technologies. Training and development helps a company to meet competitive challenges and environmental changes. Yet we highlight from the outset that information communication technologies have introduced a new set of educational opportunities for educators and students.

Training refers to a planned effort by a company to facilitate employees' learning of job-related competencies. These competencies include knowledge, skills, or behaviours that are critical for successful job performance. The goal of training is for employees to master the knowledge, skill, and behaviours emphasized in training programs and to apply them to their day-to- day activities. For many training professionals and educationalists, enthusiastic about seeking improved methods of facilitating the learning process, the answer to increasing quality within educational provision seems to lie in the use of e-learning. Daniel (1998) suggests that e-learning can be used in a flexible manner to suit the requirements of the individual students, based on asynchronous communication. According to French et al. (1999), e-learning also offers the opportunity to gain requisite continuing professional development to professionals who might otherwise find it difficult to attend programmes of study or conferences.

Electronic learning is a process of information handling by means of the Internet and other information technologies. Waller \& Wilson (2003) define e-learning as "the effective learning process created by combining digitally delivered content with (learning) support and services". The European E-learning Action Plan (2001) (noted by Rutkauskiene \& Butkevičienè 2007) describes e-learning as "the use of new multimedia technologies and the Internet to improve the quality of learning by facilitating access to resources and services as well as remote exchanges and collaboration." A 
similar definition is offered by Jackson (2002) who defines e-learning, using a definitional dichotomy which distinguishes between the use of technology to achieve enhanced learning (when learner audience has frequent opportunities to meet face-to-face with the instructor in traditional classroom) and delivered learning (where the learner audience is never or very rarely in physical proximity to the instructor and instructor-led traditional classroom sessions are either eliminated, or replaced with real time virtual classrooms).

\section{The place of training in the organisation}

Training refers to a planned effort by a company to facilitate employees' learning of job-related competencies. These competencies include knowledge, skills, or behaviours that are critical for successful job performance. The goal of training is for employees to master the knowledge, skill, and behaviours emphasized in training programs and to apply them to their day-today activities. Many organizations recognize the importance of continuous learning for meeting business challenges and providing a competitive advantage, so the role of training in companies is changing. Hence, in recent years the role of training has evolved from a program focussed approach to a broader focus on learning and creating and sharing knowledge (Baldwin et al. 1997; Martocchio, Baldwin 1997; Brinkerhoff, Apking 2001). Thus, while training continues to involve programs to teach specific skills, there is an increasing emphasis on devising methods which emphasise broader learning particularly through creating and sharing knowledge (Noe 2005). This approach to training, which seeks to develop knowledge and skills placed a heavy emphasis on both the role of the learner and the strategic importance of continuous learning.

Strategic training and development process is vital for the process of organizational change. For example, if the implementation of e-learning is to be successful, there is a need for a strategic alignment of institutional interests coupled with effective leadership. Proposed goals need to be agreed through consensual debate by various stakeholders that have an interest in organizational issues, such as senior management or board members, strategists and policy-makers, financial managers or administrators, evaluators, and possibly even shareholders in some cases.

In recent years, the development of e-learning has provided opportunities for enabling interaction between individuals and groups and allowing learners to share information. Indeed, it can have a significant impact on teaching, learning and training by providing access to new information sources on the Internet for educationalists, researches and learners. As industry increasingly adopts technological solutions to make information available to employees through a broad set of internetbased collaborative technologies, businesses become virtual workplaces. Therefore in the next sections, elearning and its associated features are discussed.

\section{E-learning and the use of technology in training}

The introduction of e-learning represents a significant change in practice that needs to be managed carefully particularly as there are a number of important components at different levels that require alignment through the process of change management. E-learning is already being used widely in education and training, and this can be exploited in the home and in community centres, as well as in universities and the workplace. Individuals are discovering that they can now access courses that were hitherto unavailable to them, making it easier for them to get involved in personal and professional learning. In addition, through the use of technology, learners can be provided with opportunities to have access to other learners in diverse contexts thus removing some of geographical constraints attached to the learning process. One of the other major potential benefits of e-learning is that it has the capability for training to proceed at a pace that it is appropriate to the learner.

In a helpful contribution, Noe (2005) has identified six levels of technology-based training. These include: communications, online referencing, testing assessment, the delivery of computer-based training and multimedia, blended learning, and electronic performance support systems. The difference between the highest and lower levels of technology-based training is that at the higher levels learning is more job-related and helps meet a business need. The simplest level facilitates communications between trainers and trainees. More complex uses of technology involve the actual delivery of training. For example, sound, automation, and video are used in Web-based training. In addition, trainees are linked to other resources on the Web. They are also required to share information with other trainees and to deposit knowledge and their insights from the training (such as potential applications of the training content) in a database that is accessible to other company employees. At the highest level - electronic performance support systems - employees receive training while they perform their jobs (Noe 2005). 
These features of e-learning give it various advantages over other training methods. E-learning initiatives can be designed to contribute to the strategic objectives. E-learning supports company initiatives such as expanding the number of customers, initiating new ways to carry out business such as e-business, and speeding the development of new products or services. E-learning may involve a larger audience than traditional training programs do that focus on employees. E-learning can reduce training time and allow training more students or employees in a shorter period of time than with traditional training methods, thus reducing training costs. Learning is enhanced through e-learning because it is possible for learners to become more engaged through the use of video, graphics, sound, and text, which appeal to multiple senses of the learners. Also e-learning requires learners to actively practise, ask questions, and interact with other learners and experts.

Consequently the adoption of an e-learning solution is becoming increasingly attractive as a solution to provide flexibility and/or to widen participation (McPherson 2003). Thus, benefits of e-learning for learners, tutors and organizations alike, have also been discussed by a number of other authors such as Stamatis et al. (1999), Nunes, Fowell (1996) and Eisenstadt, Vincent (1998). These potential benefits of e-learning can be summarized as follows:

- Electronic distribution of course material;

- Flexibility for learners - when to study, at what place;

- Supporting different learning styles;

- Accommodation of different ability levels;

- Establishment of communication between learners and tutors;

- Engendering contact between learners;

- Greater access to information;

- Greater flexibility in maintaining and up-dating course documentation.

Yet given these potential benefits of e-learning, questions immediately arise as to why e-learning has not been adopted on a more universal basis. That is, why there is still reluctance to make more extensive use of e-learning in training and development contexts.

In addressing this 'resistance to e-learning' question, Reeves, Hedberg (2003) propose that most e-learning environments remain mired in outmoded educational methods. They feel that the effectiveness of technology in any learning environment depends upon the degree that it supports appropriate "pedagogical" dimensions. Another problem is that although many educationalists are expert in their subject area, they are as yet relatively inexperienced in methods for online teaching and learning (McPherson et al. 2003). Additionally, many students are, as yet, ill-equipped for the demands of e-learning (Nunes et al. 2000). This being the case, the question must be asked whether e-learning can be successful. Another perspective on e-learning resistance is offered by Noe (2005) who suggests that various factors limit the use of e-learning. These factors include: cost; lack of motivation among employees to learn online; lack of management buy-in; lack of employee intranet access; lack of proof concerning return on investment; lack of high-quality content.

\section{Survey of learning methods practices in Lithuanian enterprises}

\subsection{Method and sample}

In order to pursue this resistance to e-learning issue further, we conducted a survey of Lithuanian companies with the aim of i) identifying employees' experiences of a range of training methods including technology and non-technology based methods and ii) exploring the types of training experienced by employees according to their current positions. The research was carried out in 18 enterprises and organisations of Lithuania of various activity profiles. 10 enterprises were manufacturing and 8 provided services (e.g. radio station, newspaper, customs intermediates, training centre, and transport enterprises). A total of 724 employees (86- managers, 219- specialists, 364-workers and 55 respondents did not indicate their position in an organisation) participated in the survey.

\section{Findings}

During the conducted research, the respondents were asked about the formal training and development methods they were experiencing in their workplace. The results are presented in Figure. As we see from the Figure, traditional development courses are a relatively common method of training with 17.89 percent of respondents experiencing development courses in the workplace. In the second place it is team work (13.33 percent) and in the third place it is observing what others do (13.07 percent). Relatively unpopular methods of training were the Internet browsing (3.36 percent) and distance learning, which attracted only 0.36 percent of the responses, thus indicating that the Internet browsing and distance learning were not, in overall terms, widely practiced training and development activities with these employees of Lithuanian organisations. 




Factors, developing employees in the Lithuanian enterprises

We also investigated how employees were trained according to their positions within the organisations. It can be seen from Table that workers are mostly trained by observing what others do (17.77 percent), development courses (16.25 percent), team work (15.49 percent) and discussing tasks with the supervisor (14.08 percent). Specialists are mostly trained by development courses (20.13 percent), discussing tasks with the supervisor (13.37 percent) and team work (11.22 percent). In the meantime managers are mostly trained by development courses (19.84 percent), performing projects (17.86 percent), team work and involvement in other work areas (both 9.52 percent).

Distribution of developing factors in percent according to the current positions

\begin{tabular}{lccc}
\hline \multicolumn{1}{c}{$\begin{array}{c}\text { Factors, developing } \\
\text { employees }\end{array}$} & $\begin{array}{c}\text { Mana- } \\
\text { gers }\end{array}$ & $\begin{array}{c}\text { Specia- } \\
\text { lists }\end{array}$ & $\begin{array}{c}\text { Wor- } \\
\text { kers }\end{array}$ \\
\hline Observation, what others do & 9,13 & 8,25 & 17,77 \\
\hline Projects performing & 17,86 & 10,89 & 5,96 \\
\hline $\begin{array}{l}\text { Involvement into other } \\
\text { work areas }\end{array}$ & 9,52 & 5,61 & 10,73 \\
\hline $\begin{array}{l}\text { Watching training programs } \\
\text { (e. g. films) }\end{array}$ & 1,59 & 0,66 & 1,3 \\
\hline Team work & 9,52 & 11,22 & 15,49 \\
\hline Instructions of others & 2,78 & 3,96 & 3,14 \\
\hline Development course & 19,84 & 20,13 & 16,25 \\
\hline Reading of handbooks & 7,94 & 6,93 & 5,63 \\
\hline Special tasks & 7,94 & 9,57 & 8,13 \\
\hline Distance learning & 1,19 & 0,66 & 0 \\
\hline Internet browsing & 3,97 & 8,09 & 1,3 \\
\hline Discussing task with the & & & \\
supervisor & 7,14 & 13,37 & 14,08 \\
\hline Other & 1,59 & 0,66 & 0,22 \\
\hline & & & \\
\hline
\end{tabular}

It is notable that the Internet browsing, while not widely practised as a training intervention, is most popular among specialists (8.09 percent). Only 3.97 percent of managers and 1.3 percent of workers use the Internet browsing for learning. 1.19 percent of managers, 0.66 percent of specialists and no workers use distance learning as a formal training mechanism. The results reveal the low level of modern information technology-based usage for employee training and development in this sample of Lithuanian enterprises.

\section{Conclusion}

The paper has focused on the use of new technology for training and development activities. The literature review highlighted that e-technology has potential advantages over more traditional training and development methods. Yet it was also noted that the adoption of new technology for training and development purposes is not a straightforward process and some degree of resistance to its introduction can be anticipated in organisations. The results of the survey show that training and development in the sample of Lithuanian enterprises has maintained a fairly traditional focus despite more global advances in e-learning technologies. This is an interesting finding that raises serious questions as to whether the lack of implementation of new technology for this purpose is resource, attitudinally and/or outcome based. As such, further research is needed to explore why this new technology has not been embraced in relation to training and development in Lithuanian enterprises of this nature.

\section{References}

Baldwin, T. T.; Danielson, C. and Wiggenhorn. 1997. The evolution of learning strategies in organizations: from employee development to business redefinition, Academy of Management Executive 11: 47-58.

Brinkerhoff, R. and Apking, A. 2001. High impact learning. Cambridge, MA: Perseus.

Daniel, J. 1998. Can you get my hard nose in focus? Universities, mass education and appropriate technology, in Eisenstadt, M. and Vincent, T. (eds.). The knowledge web: learning and collaborating on the net. London, Kogan Page.

Eisenstadt, M. and Vincent, T. 1998. The knowledge web: learning and collaborating on the net. London, Kogan Page.

French, D. 1999. Preparing for Internet - based learning, in French, D.; Hale, C.; Johnson, C. and Farr, G. (eds.). Internet based learning: an introduction and framework for higher education and business. London, Kogan Page. 
Jackson, R. H. 2002. Defining e-Learning [online]. Available from Internet: <http://hkwebsym.org.hk/2002/jackson_quote.html>.

Martocchio, J. J. and Baldwin, T. T. 1997. The evolution of strategic organizational training, Research in Personnel and Human Resource Management 15 (ed. G. R. Ferris). Greenwich, CT: JAI Press, 1-46.

McPherson, M. A. 2003. Planning for success in e-learning in HE: a strategic view, in Jakab, F. and Cizmar, A. (eds.). Proceedings of the $2^{\text {nd }}$ International Conference on Emerging Telecommunications Technologies and Applications and the $4^{\text {th }}$ Conference on Virtual University (ICETA 2003), 11-13 September 2003, Kosice, Slovak Republik, 449-452.

McPherson, M. A.; Nunes, J. M. and Zafeiriou, G. 2003. New tutoring skills for online learning: are e-tutors adequately prepared for e-learning delivery? in Szucs, A.; Wagner, E. and Tsolkidis, C. (eds.). Proceedings of the $12^{\text {th }}$ European Distance Education Network Annual Conference on The Quality Dialogue; Integrating Quality Cultures in Flexible, Distance and eLearning (EDEN 2003), 15-18 June 2003, Rhodes Palace Hotel, Rhodes, Greece, 347-350.

Noe, R. A. 2005. Employee training and development (Third Edition). The McGraw Hill.
Nunes, J. M. and Fowell, S. P. 1996. Hypermedia as an experiential learning tool: a theoretical model, Information Research 2, 1, August [online]. Available from Internet: $<$ http:// informationr.net/ir/2-1/paper12html $>$.

Nunes, J. M.; McPherson, M. A. and Rico, M. 2000. Design and development of a networked learning skills modules for web based collaborative distance learning, in Proceedings of the $1^{\text {st }}$ ODL International Workshop, 2000, Universidad Politecnica de Valencia, centro de Formacion de Postgrado, Valencia, Spain, 19-21 July 2000, 117-131.

Reeves, T. and Hedberg, J. 2003. Interactive learning systems evaluation. Englewood Cliffs, NJ, Educational Technology Publications.

Rutkauskienė, D. and Butkevičienė, E. 2007. Distance education from the perspective of educators: opportunities and challenges, in Advanced Learning Technologies and Applications (ALTA'2007). Conference proceedings. Kaunas.

Stamatis, D.; Kefalas, P. and Kargidis, T. 1999. A multiagent framework to assist networked learning, Journal of Computer Assisted Learning 15(3): 201-210.

Waller, J. and Wilson, J. 2003. E-learning definition [online]. Available from Internet: <http://www.odlqc.org.uk/odlqc/ n19-e.htm>. 